\title{
PENGEMBARAAN SERAT CENTHINI DALAM CENTHINI LES CHANTS DE L'TLE A DORMIR DEBOUT DAN IA YANG MEMIKUL RAGANYA: INTERPRETASI, INOVASI DAN DISTORSI DALAM PENERJEMAHAN
}

\author{
Wening Udasmoro \\ Program Studi Sastra Prancis Fakultas Ilmu Budaya \\ Universitas Gadjah Mada \\ weningw@yahoo.com
}

\begin{abstract}
ABSTRAK. Serat Centhini telah mengalami pengembaraan dalam proses penerjemahan. Dari teks Jawa kuno, serat tersebut dialihbahasakan ke dalam bahasa Indonesia. Ia kemudian juga mengalami transliterasi ke dalam Bahasa Prancis setelah kemudian teks dari Bahasa Prancis tersebut dikembalikan ke dalam Bahasa Indonesia. Centhini menjadi mahakarya yang mengalami perjalanan interpretasi yang panjang, mengalami transformasi alih bahasa dan alih budaya serta proses pengaktualisasian pemikiran dan ide akibat campur tangan penerjemah ketika proses pengalihan bahasa tersebut terjadi. Yang menjadi persoalan, begitu mudahkah penerjemahan yang bertingkat tersebut dilakukan? Apabila penerjemahan dari satu teks saja memunculkan beragam distorsi, bagaiamana dengan penerjemahan multi tingkat ini? Interpretasi seperti apakah yang dilakukan penerjemah? Adakah inovasi dan distorsi yang terjadi sebagai hasil dari proses penerjemahan? Tujuan artikel ini adalah merunut pengembaraan penerjemahan Serat Centhini dengan fokus pada interpretasi, inovasi dan distorsi yang dilakukan oleh para penerjemah.
\end{abstract}

Kata kunci: Centhini, terjemahan, interpretasi, inovasi, distorsi

\section{THE ADVENTURE OF SERAT CENTHINI IN LES CHANTS DE L'TिLE A่ DORMIR DEBOUT AND IA YANG MEMIKUL RAGANYA: INTERPRETATION, INOVATION AND DISTORSION IN THE PROCESS OF TRANSLATION}

\begin{abstract}
The Serat Centhini novel has been translated from Javanese language to Indonesian, then French and back to the Indonesian language. Serat Centhini has been experiencing a long process of transformation such as in the changing of linguisic and cultural code. In a single process of translation, some distortions may have occured. Moreover, in the multi process of translation may be more problems related to distortion, interpretation and innovation done by the different translators. Crucially, several related questions arise: What interpretation a translator may invent in the translation? Are there any distortion and innovation done by the translator? This article attempts to analyse the interpretation, innovation, and distortion of Serat. Centhini from different versions done by various translators.
\end{abstract}

Key words: Serat Centhini, translation, interpretation, innovation, distortion 


\section{PENDAHULUAN}

Serat Centhini yang dikenal orang Indonesia sebagai karya sastra adiluhung Jawa yang ditulis pada abad sekitar tahun 1814 telah menarik minat banyak orang Prancis untuk membacanya. Serat Centhini disusun berdasarkan kisah perjalanan putra-putri Sunan Giri setelah dikalahkan oleh Pangeran Pekik dari Surabaya, ipar Sultan Agung dari Kerajaan Mataram. Kisah dimulai setelah tiga putra Sunan Giri berpencar meninggalkan tanah mereka untuk melakukan pengembaraan. Mereka adalah Jayengresmi, Jayengraga atau Jayengsari, dan seorang putri bernama Ken Rancangkapti. Serat tersebut berisi banyak hal berbagai macam bentuk ajaran dalam kehidupan serta penyebaran Islam di Jawa (Sumahatmaka, 1981). Akan tetapi, karena serat ini seringkali menjadi lebih dikenal karena ada muatan-muatan seksualitas yang cukup terbuka bahkan untuk pembaca masa kini (Nurnaningsih, 2010). Salah satu aspek yang diketengahkan yang menarik banyak orang untuk membacanya misalnya adalah masalah homoseksualitas (Boellstorff, 2005).

Begitu menariknya bagi pembaca di Indonesia dan Prancis, Serat Centhini telah mengalami proses penerjemahan bertingkat. Pertama, karya itu diterjemahkan dari teks asli berbahasa Jawa dan berhuruf Jawa ke dalam bahasa Jawa berhuruf Latin. Pada tahap kedua, karya sastra berbahasa Jawa berhuruf Latin tersebut diterjemahkan ke dalam bahasa Indonesia. Sedikitnya ada dua orang penerjemah untuk versi ini, yakni penerjemahan yang dilakukan oleh Tardjan Hadidjaja dan Kamajaya (1979) yang berjudul Serat Centhini; Ensiklopedi Kebudayaan Jawa dan penerjemahan oleh sebuah tim dari Jurusan Sastra Nusantara Fakultas Ilmu Budaya UGM yang diketuai oleh Profesor Marsono (2005) terbitan Gadjah Mada University Press berjudul Centhini TambangrarasAmongraga.

Dari versi berbahasa Indonesia tersebut, Serat Centhini diterjemahkan atau lebih tepatnya diintepretasikan oleh Elisabeth Inandiak (2005), seorang jurnalis dan penulis Prancis ke dalam bahasa Prancis dengan judul Les Chants à Dormir Debout: Le Livre de Centhini. Yang menarik, versi terjemahan dari bahasa Prancis tersebut diterjemahkan kembali ke dalam bahasa Indonesia setelah mengalami proses penerjemahan inovatif oleh Laddy Lesmana dan Elisabeth Inandiak (2007). Menurut Inandiak, Serat Centhini telah mengalami pengembaraan ke daratan Eropa dan saat ini pulang kampung ke tanah Jawa. Centhini menjadi mahakarya yang mengalami perjalanan interpretasi yang panjang, mengalami transformasi alih bahasa, alih kode dan alih budaya serta proses pengaktualisasian pemikiran dan ide akibat campur tangan penerjemah ketika proses pengalihan bahasa tersebut terjadi. Serat Centhini telah menjadi salah satu karya sastra Jawa yang menarik bagi orang-orang Prancis untuk diapresiasi terbukti dengan adanya terjemahan berulang-ulang terhadap karya tersebut.

Dapat dibayangkan bahwa ketika Serat Centhini dituliskan ulang ke dalam bahasa Jawa dengan huruf Latin, maka akan banyak kemungkinan muncul distorsidistorsi. Dalam bahasa Jawa, penulisan huruf yang berbeda, misalnya a dan o, akan memunculkan perbedaan makna. Penulisan dari bahasa Jawa berhuruf Latin 
ke dalam bahasa Indonesia juga mengalami berbagai interpretasi. Apalagi bila karya itu diterjemahkan oleh beberapa orang dengan latar belakang bahasa dan budaya yang berbeda. Distorsi-distorsi kemungkinan besar muncul karena setiap pengarang akan mengartikan suatu kata atau frasa dan wacana dengan style dan pemahaman dan konteks budaya mereka. Ketika penulisan itu masih dalam bahasa yang sama maka hanya mengalami alih tulisan, misalnya dari huruf Jawa ke Latin. Akan tetapi, ketika yang dilakukan adalah alih bahasa secara total, yakni dari bahasa Jawa ke bahasa Indonesia, akan ada kompleksitas yang semakin rumit.

Kompleksitas yang akan pertama kali muncul adalah persoalan alih bahasa yang berkonsekuensi pada perubahan-perubahan arti atau makna akibat proses penerjemahan. Kedua adalah persoalan terjadinya distorsi-distorsi akibat alih bahasa yang tidak lengkap. Yang sering terjadi adalah pengartian yang tidak tepat karena kesalahpahaman kultural. Sebagai contoh, karya Pramudya Ananta Toer (1980) Bumi Manusia diterjemahkan ke dalam bahasa Prancis dengan judul le Monde des Hommes. Pada salah satu bagian cerita, dikisahkan tentang cara-cara orang Jawa berpuasa. Salah satunya adalah puasa Mutih. Penerjemah mengartikan bahwa puasa Mutih berarti berpuasa dengan tidak makan nasi putih. Padahal, makna dari puasa ini menurut orang Jawa justru sebaliknya, yakni hanya diperbolehkan makan nasi putih dan minum air putih (Faridl, 2007).

Pemaknaan lain akan muncul ketika proses yang terjadi bukan sekedar menerjemahkan tetapi sekaligus penginterpretasian dan penulisan ulang Centhini. Hal inilah yang dilakukan oleh Elisabeth Inandiak. Penulis Prancis yang telah lebih dari dua puluh tahun tinggal di Indonesia ini mencoba menulis ulang Centhini ke dalam bahasa ibunya, yakni bahasa Prancis. Ia berusaha mengadaptasi tidak hanya dari segi bahasa, tetapi juga dari segi ide serta gaya penderitaan. Hal ini terlihat dari cara penulis ini menggunakan referensi-referensi yang mendukung dari tiap tembang yang dijadikan bab-bab dalam bukunya yang berjudul Les Chants de lîle à Dormir Debout. Dengan demikian, Inandiak tidak hanya menerjemahkan Serat Centhini ke dalam bahasa Prancis tetapi sekaligus memasukkan ide-ide interpretatif dan adaptif sesuai dengan konteks sebagai penulis yang merupakan orang Prancis tetapi yang juga memahami budaya Jawa. Setelah melalui proses tersebut, cerita Centhini yang telah diolah dengan pemikiran Inandiak tersebut dialihbahasakan kembali ke dalam bahasa Indonesia. Yang menjadi persoalan, akankah Centhini memiliki wajah sesuai dengan aslinya? Bagaimana dengan pengaruh pemikiran-pemikiran penulis ke dalam Centhini versi yang baru tersebut? Interpretasi, inovasi dan distorsi seperti apakah terjadi sebagai hasil dari proses penerjemahan?

Pengembaraan Serat Centhini inilah yang menarik untuk dicermati. Sepengetahuan penulis, belum pernah ada karya yang diterjemahkan dari suatu bahasa sumber ke bahasa tujuan dan dikembalikan lagi ke bahasa sumber dengan versi yang berbeda. Penerjemahan bebas dan inovatif yang dilakukan dalam proses penerjemahan ini diasumsikan membawa ke suatu bentuk baru yang mungkin sudah tidak mudah dikenali kembali. Penerjemahan yang bertingkat ini 
pada saat yang bersamaan mengubah secara bertingkat interpretasi yang dilakukan. Diasumsikan akan adanya interpretasi, inovasi dan distorsi-distorsi yang muncul karena penerjemahan bertingkat tersebut meskipun tidak dapat dikatakan bahwa hal itu negatif. Penerjemahan ini di satu sisi dianggap sebagai bentuk pengkhianatan pada pakem sebuah karya tetapi di sisi lain merupakan penyegaran terhadap bentuk-bentuk penerjemahan yang terlalu setia sehingga jiwa dan makna penerjemahan seringkali menjadi sangat sulit untuk dipahami. Tulisan ini akan melihat versi penerjemahan dari bahasa Indonesia Serat Centhini ke dalam bahasa Prancis, yakni Centhini Les Chants à Dormir Debout dan dari bahasa Prancis ke dalam bahasa Indonesia, yakni 'Ia Yang Memikul Raganya'.

Tujuan artikel ini adalah merunut pengembaraan penerjemahan Serat Centhini dengan fokus kepada interpretasi, inovasi dan distorsi yang dilakukan oleh penerjemah. Pemahaman terhadap ketiga aspek ini memungkinkan peneliti melihat secara teoritis kebaruan-kebaruan dalam hal penerjemahan terutama pada karya sastra dan secara praktis mencermati metode yang digunakan oleh penerjemah

Selain teori penerjemahan, aspek yang tidak kalah menarik untuk menjadi theoretical framework adalah masalah interpretasi dalam karya sastra yang sebetulnya merupakan tataran awal dari proses penerjemahan itu sendiri. Hal-hal yang mendapatkan perhatian dalam teori penerjemahan itu adalah permasalahan kreativitas (inovasi) yang dilakukan penerjemah (Durieux, 2000; Jacobsen, 2009). Dalam aspek kreativitas ini, hal-hal yang mendapatkan perhatian adalah masalah komunikasi dan keinginan untuk mengatakan secara bebas meskipun dalam koridor teks yang ditaati secara kreatif. Dalam persoalan kreativitas ini ada beberapa hal yang biasanya menjadi pertimbangan penerjemah agar menjadi kreatif. Pertama adalah kreatif dalam persoalan diksi. Pemilihan kata adalah salah satu aspek yang dapat menjelaskan kekayaan pengetahuan penerjemah dalam hal kosa kata. Penerjemah yang dianggap kreatif biasanya memiliki deretan sinonim yang lengkap untuk kata-kata yang digunakan. Tujuannya adalah untuk menunjukkan variasi-variasi kata sehingga menghindari pengulangan kata yang akan membuat pembaca bosan ketika membacanya. Kata-kata yang tepat ketika digunakan berpengaruh pula pada sens-sens tertentu, misalnya persoalan romantisme, ketepatan makna dan sebagainya. Sebagai contoh, kata aimer dalam bahasa Prancis ketika diterjemahkan ke dalam bahasa Indonesia dapat berarti mencintai, atau menyayangi, sebuah pemakaian yang berbeda dengan konteks di Indonesia yang lebih detil. Penggunaan yang tepat tentu saja diperlukan konteksualitas yang jelas terutama terkait dengan subjek-subjek yang ada di dalam cerita yang diterjemahkan.

Kreativitas kedua adalah persoalan penyusunan kalimat. Seorang penerjemah yang berpengalaman biasanya memperhatikan persoalan ini. Susunan kalimat aktif tidak selalu diterjemahkan dengan susunan kalimat yang sama. Hal ini karena setiap bahasa memiliki susunan kalimat ini yang berbeda untuk menunjukkan makna tertentu. Sebagai contoh, bahasa Prancis lebih banyak menghindari 
susunan kalimat pasif. Sementara itu, bahasa Indonesia lebih banyak memberikan perhatian pada susunan kalimat pasif.

Kreativitas ketiga, yang juga merupakan kreativitas total penerjemahan dan interpretasi adalah bermain-main dengan berbagai konteks yang dapat mendukung proses penerjemahan. Salah satu hal yang dapat dilakukan adalah dengan menggunakan referensi-referensi yang dapat mendukung hasil penerjemahan. Sebagai contoh, ketika cerita yang diterjemahkan berbau sufisme, penerjemah menggunakan buku-buku atau referensi-referensi tentang sufisme yang dapat bermanfaat dalam penginterepretasian karya tersebut.

Hal kedua yang mendapatkan perhatian adalah masalah pedagogi penerjemahan (Lavault, 2000). Aspek-aspek yang diperhatikan dalam pendekatan ini adalah fungsi penyampaian pesan yang tidak hanya bersifat dari teks ke teks tetapi menyangkut persoalan budaya yang ditransferkan. Konteks budaya ini sangat penting untuk menghindari distorsi-distorsi serta kesalahan-kesalahan dalam pemaknaan. Seringkali, salah satu kesuksesan penerjemahan adalah karena penerjemah memahami secara personal konteks budaya suatu karya yang diterjemahkannya. Maksudnya, penerjemah tidak hanya meraba-raba arti dengan cara melihat kamus atau ensiklopedi dalam proses penerjemahan tetapi memahami secara situasional suatu hal yang dimaksudkan dalam cerita yang diterjemahkannya. Sebagai contoh, un jardinier dalam bahasa Prancis apabila diartikan ke dalam bahasa Indonesia berarti tukang kebun. Namun, dalam konteksnya, un jardinier ini memiliki perbedaan-perbedaan antara Indonesia dan Prancis. Un jardinier dalam konteks Prancis bukan hanya mereka yang bertugas atau membersihkan kebun. Mereka adalah designer sebuah taman yang biasanya diberi tugas membentuk taman-taman yang cantik dengan variasi bunga yang selalu berubah di setiap musimnya. Mereka bahkan mungkin tidak harus membersihkan kebun karena sudah ada pekerja lain yang melakukannya.

Hal ketiga yang dipertimbangkan adalah persoalan evaluasi dalam penerjemahan (Le Féal, 2000). Evaluasi dilakukan dalam penerjemahan yang menghubungkan pula dengan konteks budaya yang dijadikan referensi dalam evaluasi tersebut. Evaluasi dilakukan dengan tujuan untuk mendekatkan karya terjemahan dengan karya aslinya. Secara ideal, penerjemahan yang dianggap sempurna adalah yang dapat membuat orang yang membaca karya terjemahan memiliki pemahaman yang sama dengan orang yang membaca karya aslinya. Paling tidak, pembaca karya-karya terjemahan memiliki perasaan yang sama dengan orang yang membaca karya aslinya. Untuk itu, hal-hal yang seringkali dilakukan oleh penerjemah salah satunya adalah dengan tetap mempertahankan konsep-konsep yang ada dan hanya memberi catatan kaki pada kata atau konsep tersebut. Sebagai contoh, konsep Habitus Pierre Bourdieu lebih sering dipertahankan penerjemah di banyak bahasa dengan tetap mempertahankan konsep tersebut. Penerjemahan secara total terhadap konsep tersebut ke dalam bahasa lain, kemungkinan besar justru akan menghancurkan pemaknaan konsep itu sendiri. 
Selain masalah penerjemahan secara teknis, dalam penerjemahan sebetulnya ada proses lain yang muncul. Proses ini berhubungan dengan pemosisian diri penerjemah terhadap dua dunia yang berbeda. Secara psikologis, ada dua identitas yang ingin dijelaskan oleh penerjemah. Di satu sisi, identitas tempat bahasa sumber berada dan di sisi lain adalah identitas tempat bahasa tujuan berada. Dalam hal ini, ada bentuk-bentuk pemosisian yang dicoba untuk dijembatani oleh penerjemah. Yang menjadi masalah adalah ketika proses penjembatanan tersebut tidak seratus persen dapat dilakukan. Persoalan seksualitas, misalnya, selalu menjadi aspek yang menyebabkan kendala dalam alih bahasa. Seksualitas yang vulgar tidak dapat selalu diterjemahkan secara maksimal. Ketika dalam konteks bahasa tertentu suatu praktik tertentu tidak ada, penerjemah seringkali membutuhkan misalnya catatan kaki untuk menjelaskan daripada mencoba mencari sinonimnya. Sebagai contoh, Ronggeng Dukuh Paruk karya Ahmad Tohari, menimbulkan kesulitan yang berbeda antara budaya di satu Negara dengan Negara lain karena konsep Ronggeng tidak selalu dimiliki setiap budaya. Seringkali penerjemah mengalami konflik-konflik dengan berusaha untuk mencari solusi-solusi yang terterima dalam proses penerjemahan.

\section{METODE}

Data untuk penelitian ini berasal dari tiga karya terjemahan, yakni Serat Centhini (2005) yang terjemahannya dilakukan tim Sastra Nusantara UGM yang dipimpin oleh Profesor Marsono, Centhini Les Chants de l'T̂le à Dormir Debout: Le Livre de Centhini karya Elisabeth Inandiak (2005) dan Ia yang Memikul Raganya yang merupakan hasil terjemahan Laddy Lesmana dan Elisabeth Inandiak (2007).

Data-data Serat Centhini tersebut sebetulnya diambil dari buku Centhini Tambangraras-Amongraga Jilid $\mathrm{V}$ yang disadur ke dalam bahasa Indonesia. Disebutkan bahwa buku tersebut adalah saduran karena berasal dari naskah bahasa Jawa dan bertuliskan huruf Latin tetapi apabila dalam bahasa sumbernya bentuknya adalah tembang-tembang dengan model pantun tetapi dalam saduran tersebut berbentuk cerita narasi dengan paragraph-paragraf seperti sebuah cerita. Jilid V ini dipilih untuk disesuaikan dengan bagian dari Centhini terjemahan ke dalam bahasa Prancis oleh Inandiak. Dengan demikian, proses pertama ini merupakan proses penyeleksian bagian-bagian yang dimunculkan untuk diterjemahkan dari ketiga versi yang ada.

Metode yang dilakukan dalam penelitian ini adalah pertama melihat secara bolak-balik kesesuaian tema agar penelusuran aspek-aspek yang sejajar dapat dilakukan untuk analisis. Sebagai contoh, dicari bagian-bagian dari Serat Centhini yang juga muncul dalam Les Chants de l'Île à Dormir Debout serta dalam Ia Yang Memikul Raganya.

Pembacaan bolak-balik ini bertujuan untuk mengetahui proses seleksi penerjemah terhadap teks yang diterjemahkan. Hal ini karena Inandiak, misalnya, melakukan seleksi terhadap teks-teks yang diterjemahkannya baik dalam Les Chants de l'Île à Dormir Debout maupun Ia Yang Memikul Raganya. Jadi, tidak 
semua teks diterjemahkan. Pada pembacaan bolak-balik ini dilakukan perhatian pada persoalan tema dari ketiganya. Namun, perlu diketahui bahwa tidak semua tema yang dipilih ada pada ketiga buku. Pada buku ketiga terutama, yang terlihat jelas penerjemah melakukan seleksi terhadap teks yang diterjemahkan.

Tahap kedua adalah pembacaan dengan melihat makna dari hasil penerjemahan dari bahasa Indonesia ke dalam bahasa Prancis tersebut dengan memperhatikan interpretasi yang dilakukan penerjemah serta inovasi dan distorsi yang mungkin muncul akibat penerjemahan. Aspek-aspek budaya yang muncul dari proses ini dicatat sebagai satu unsur dalam analisis.

Pada tahap ketiga, dilakukan hal yang sama untuk versi dari bahasa Prancis ke dalam bahasa Indonesia. Dengan demikian, aspek bahasa dan interpretasi serta inovasi dan distorsi yang muncul dilihat secara detil dengan dasar pada representasi budaya yang hadir pada penerjemahan tersebut. Sampel-sampel dibutuhkan sebagai korpus data yang akan diteliti.

Setelah mengalami proses pengkodean data, maka dilanjutkan dengan analisis terhadap data-data tersebut. Pada analisis terhadap data ini diperlukan dukungan dari hermeneutika (Eco, 1979; Palmer, 1969) yang membantu melihat aspek-aspek budaya yang hadir dalam penerjemahan tersebut.

Pembacaan dengan hermeutika ini selanjutnya adalah untuk melihat bahwa proses interpretasi oleh penerjemah sebenarnya mengikutsertakan dua proses. Proses pertama adalah bahwa teks itu sebenarnya merupakan satu kesatuan yang objektif. Teks memberi arti pada teks itu sendiri. Namun, penerjemah dengan storage atau prejudice atau prior text-nya memberikan kontribusi subjektif terhadap pemaknaan interpretasi (Palmer, 1969).

\section{HASIL DAN PEMBAHASAN}

Dalam konteks penerjemahan bertingkat centhini ini, ada hal yang menarik untuk dicermati. Terkait dengan persoalan interpretasi, analisis dapat diawali dari seleksi terhadap teks oleh penerjemah. Dalam setiap penerjemahan, baik dari bahasa Indonesia ke Prancis atau dari bahasa Prancis ke Indonesia, para penerjemahnya telah melakukan proses seleksi terhadap teks. Seleksi pertama adalah terkait dengan bentuk teks. serat Centhini dalam bentuk pantun, diubah menjadi bentuk-bentuk paragraf yang lebih menyerupai cerita daripada puisi. Seleksi kedua adalah terkait dengan seleksi terhadap bagian teks yang diterjemahkan dan yang tidak diterjemahkan. Dalam arti, ketika tidak ada bagian tertentu pada buku ini padahal ada pada bagian lain, maka sebetulnya penerjemah sudah menunjukkan interpretasi terhadap suatu hal. Dengan demikian, sudah ada proses pengeliminasian terhadap satu aspek yang memang mungkin disengaja oleh penerjemah atau penginterpretasi.

Berdasarkan penelitian mengenai bagian-bagian yang diseleksi oleh penerjemah, terlihat bahwa ada yang dihindari untuk diterjemahkan. Bagian yang tidak diterjemahkan tersebut antara lain merupakan salah satu bagian yang sangat sensitif karena berisi hubungan-hubungan seksual tokoh-tokoh di dalamnya. Yang 
menjadi lebih spesifik, ada fenomena homoseksualitas yang muncul yang pada dasarnya merupakan persoalan yang cukup tabu dalam masyarakat secara keseluruhan. Secara kontekstual, ada perbedaan persepsi mengenai persoalan homoseksualitas ini dalam masyarakat Indonesia dan Prancis. Homoseksualitas dalam masyarakat Prancis aktual adalah tindakan yang secara konstruktif terterima secara hukum dan menjadi isu hak azasi manusia. Sementara itu, dalam masyarakat Indonesia, homoseksualitas adalah persoalan realitas yang hidup dalam masyarakat, dipahami tetapi tidak dieksplisitkan dalam persoalan hukum. Perkawinan homoseksual, menjadi isu penting dalam masyarakat Prancis tetapi tidak terdiskusikan dalam konteks Indonesia. Yang menjadi persoalan, ketika penerjemah, yakni Elisabeth Inandiak, yang mencoba menerjemahkan realitas dalam cerita Jawa yang sudah diterjemahkan dalam bahasa Indonesia itu, mampukan menjembatani perbedaan fenomena tersebut. Persoalan seksualitas yang sensitif ini menimbulkan persoalan dalam pengalihan bahasa ketika pun penerjemah tidak dapat seluruhnya menghindari untuk menerjemahkannya. Hal ini karena penerjemah harus mampu mentransfer sebuah ide tabu ke dalam kalimatkalimat yang terterima oleh pembaca masa kini.

Terkait dengan persoalan distorsi, bila dalam Serat Centhini versi Sastra Nusantara UGM, penerjemah menggunakan narasi dengan diberi judul-judul sesuai dengan isi cerita, dalam Les Chants de l'Île à Dormir Debout, Elisabeth Inandiak menggunakan beberapa pembagian bab yang berbeda. Keseluruhan Serat Centhini yang telah disadur dan diterjemahkan ke dalam bahasa Prancis tersebut dijadikan beberapa bab dengan judul-judul utama, seperti Génélogie, la Guerre dan sebagainya yang di dalamnya ada beberapa chants atau tembang. Versi bahasa Indonesia terjemahan dari karya Prancis ini, yakni versi "Centhini Ia Yang Memikul Raganya" dibuat dalam pembagian bab yang sama. Namun, pada penerjemahannya, penerjemah melakukan pemilihan terhadap tembang-tembang yang ada dalam versi bahasa Prancis. Dengan demikian, tidak semua tembang diterjemahkan. Dengan demikian, kembali terjadi proses interpretasi dengan cara seleksi terhadap teks yang dengan serta merta menciptakan distorsi-distorsi baru karena penghilangan bagian-bagian yang diterjemahkan. Yang menarik untuk dicermati adalah bahwa bagian yang terdistorsi adalah yang berisi petualangan Cebolang dengan tindak-tindak homoseksualitas.

Pada Serat Centhini Tambangraras-Amongraga hasil terjemahan Tim Sastra Nusantara, cerita yang dianalisis ada pada Jilid $\mathrm{V}$ bagian 1 dengan judul Mas Cebolang dan Para Santrinya di Kabupaten Wirasaba. Sementara itu, padavversi Centhini Les Chants de l'T̂le à Dormir Debout, bagian yang dianalisis adalah La Fugue de Cebolang Chants 51 dan sampai 54 (Pelarian Diri Cebolang). Pada Centhini, Ia yang Memikul Raganya, bagian yang ada pada dua buku versi Indonesia dan Prancis tersebut di atas tidak muncul dalam penerjemahannya. Hal ini terkait persoalan psikologis penerjemah yang menarik untuk diteliti.

Terkait dengan persoalan inovasi, kebaruan yang muncul adalah dengan mengubah bentuk-bentuk terjemahan dan juga cara menerjemhkan yang 
sedemikian bebas bahkan dengan memasukkan unsure-unsur ide dari pengarang Prancis lain. Pada Serat Centhini Tambangraras-Amongraga, bagian teks yang dipilih untuk dianalisis berasal dari Pupuh 321 Tembang Sinom (mulai bait 40-86) dengan judul Mas Cebolang dan Para Santrinya di Kabupaten Wirasaba. Sebelum menuju ke bagian lain, setidaknya ada 27 halaman yang menjelaskan cerita ini. Kisah garis besarnya adalah ketika Mas Cebolang berada di Kabupaten Wirasaba, menjadi penari dan disukai oleh Kiai Adipati. Selain disukai Adipati, Cebolang dan Nurwitri pengikutnya juga disukai oleh para istri Adipati. Keduanya menjadi contoh playboy Jawa masa lampau yang menggunakan kehebatan estetis mereka, dalam hal fisik dan kemampuan kultural, misalnya menari dan bermain sulap. Yang menarik adalah relasi-relasi kekuasaan yang saling tarik menarik dalam cerita tersebut. Di satu sisi, secara sosial Cebolang dan Nurwitri berada dalam kekuasaan Adipati, tetapi secara seksual, mereka menguasai Adipati beserta para istrinya.

Dalam bagian ini, dijelaskan secara detil hal-hal yang dilakukan oleh Mas Cebolang, seperti memainkan alat musik, menari termasuk impresi orang-orang Kabupaten terhadap Cebolang dan Nurwitri. Sifat-sifat serta tindakan serta karakter Cebolang, Nurwitri dan tokoh-tokoh lain dijelaskan secara panjang lebar. Berikut ini adalah karakter Cebolang:

"Oleh karena sikapnya yang kenes, ganas, suka berlaku serong, nunjang kuping, ia menginginkan yang memainkan rebana. Melirik-lirik matanya, dan jika dilihat oleh kiai Adipati ia mendekat ke depan. Kalau sudah ditinggal pergi oleh kiai Adipati, ia segera menjual kecantikan dengan melayangkan kerlingan (Centhini, 2005: 6)."

Dalam versi terjemahan Prancis Les Chants de lî̂le à Dormir Debout, narasinarasi yang berkepanjangan tersebut tidak seluruhnya ditulis. Jika dalam versi Centhini Tambangraras-Amongraga ada penulisan secara lengkap persoalan nuansa, situasi dan kejadian, maka pada versi Les Chants de l'̂́le à Dormir Debout, urutan kejadian mendapatkan porsi yang signifikan. Keadaan ketika Cebolang menarik hati kiai Adipati diceritakan sebagai berikut :

"Il se fit escorter par les serviteurs qui l'introduisirent dans la pièce du fond où se trouvait déjà Nurwitri assis auprès du régent. Les deux garçons échangèrent un sourire entendu (Inandiak, $2002:$ 188).

Ia dibawa para pelayan yang ke dalam sebuah ruangan yang di situ Nurwitri sudah duduk di sebelah Bupati. Kedua pemuda itu saling melempar senyum paham satu sama lain. "

Ada pemangkasan yang cukup signifikan sehingga terlihat bahwa penerjemah melakukan interpretasi yang sangat jauh dari yang diceritakan. Distorsi yang muncul terkait dengan suasana, karakter dan detil tentang situasi yang dilakukan. 
Akan terapi muncul inovasi baru yang terlihat, yakni hadirnya bentuk teks baru yang adaptif dengan kultur Prancis atau yang mudah dipahami oleh kultur Prancis.

Bagian ketika Cebolang berada di Kabupaten Wirasaba sama sekali tidak diterjemahkan oleh Inandiak dan Lesmana ke dalam bahasa Indonesia. Mereka hanya menuliskan ringkasan untuk bagian ini. Mengapa bagian ini dilewati oleh kedua penerjemah ? Hal ini menarik untuk disimak. Perlu diketahui bahwa bagian ini sarat dengan adegan-adegan seksual yang sangat detil terutama dalam hubungannya dengan homoseksualitas. Kemungkinan besar hal inilah yang menjadi pertimbangan dasar yang menyebabkan bagian ini tidak secara lengkap diterjemahkan. Dengan demikian kembali interpretasi dalam bentuk penyeleksian terhadap teks menimbulkan distorsi dengan lenyapnya satu bagian yang sebetulnya sangat menarik bagi pembaca. Akan terapi, kembali muncul inovasi terkait dengan pentingnya Centhini sebagai teks yang layak untuk dibaca semua kalangan karena ketidakhadiran bagian-bagian tersebut.

Persoalan seksualitas menjadi hal sangat ketat dijelaskan pada bagian ini, terutama pada versi Tembangraras.

"Mereka di belakang selalu melekat menjadi satu. Ia penuh nafsu bersekehendak. Kemudian kain disibakkan dan senjata panahnya, canggung hendak melaksanakan keinginannya, mendesah-desah bagaikan gasingan, bergumul tidak dapat menahan hawa nafsu. Nurwitri melonjak, membungkuk dan hatinya berdebar, melilit, mendesah dan berkata perlahan. "Perlahan-lahan saja." (Marsono, 2005: 15)."

Narasi di atas secara umum mungkin masih dianggap sebagai ekspresi seksualitas yang biasa dalam sebuah tulisan. Namun, ada bagian-bagian lain yang kemungkinan besar dianggap sebagai sesuatu yang vulgar apalagi jika diasosiasikan dengan masa lahirnya karya tersebut. Di bawah ini dijelaskan tindakan seksual yang seringkali dikatakan "tidak biasa" tersebut. Tindakan tersebut adalah homoseksualitas yang dilakukan oleh Mas cebolang dengan kiai Adipati.

Seperti diketahui bahwa sebuah karya tidak lahir dari kekosongan budaya. Situasi sosial, politik dan kultural membangun sebuah karya tumbuh sesuai dengan jiwa tempat karya tersebut berada. Dalam karya sastra Indonesia, persoalan homoseksualitas tidak dapat dikatakan tumbuh subur sebelum masa Reformasi setelah tahun 1998. Setelah masa ini, banyak karya-karya yang mendapatkan angin segar untuk mengetengahkan persoalan-persoalan homoseksualitas.

Bisa dibayangkan bahwa persoalan homoseksulitas tumbuh subur setelah tahun 1998. Namun, Serat Centhini secara detil telah menjelaskan fenomena tersebut. Contoh dari fenomena homoseksualitas tersebut adalah sebagai berikut. 
"Mas Cebolang segera mengucapkan mantra pengotong-otong dengan cekatan. Kelaminnya sungguh besar, keras lagi dan tajam. Setelah masuk dalam lubang ditekan, tulang pangkal dengan segera menekan dan tiba-tiba keluar dengan deras. Kiai Adipati meloncat karena terperanjat, menjadi gelap pandangannya dan berkunang-kunang, hatinya berdebar. Terkoyak, terpercik, terengah-engah tidak dapat bergerak, sebab disedot sampai habis (Marsono, 2005: 23)."

Bagian ini diterjemahkan oleh Elisabeth Inandiak dalam Les Chants de l'T̂le à Dormir Debout sebagai berikut :

"Cebolang le cajola de mots doux tout en caressant les régions escarpées de son anus. Le régent était sous le charme, il oublia qu'il était un homme, il se sentit devenir femme, son pagne glissa, la venge de Cebolang travaillait dur pour forcer son entrée. Il prononça alors une de ces formules abracadabracantes dont il avait le secret, son phallus se raidit davantage et plongea enfin dans l'orofice offert.

Le régent sursauta, sa vue se trouble, il se sentit pris de vertiges. Cebolang le pénétra jusqu'aux confins de son être. Le régent hurla : «Assez! Non! Ça suffit! Retire ton gros poisson de mon aquarium ! (Inandiak , 2002 : 192)."

Bagian ini secara khusus diterjemahkan isi ceritanya oleh Inandiak ke dalam Bahasa Prancis. Namun, dapat dikatakan bahwa Inandiak lebih dapat dikatakan menginterpretasi daripada menerjemahkan atau mengalihbahasakannya. Ada beberapa hal yang melandasi argumen ini. Pertama, tidak ada urutan kalimat yang sama. Yang ada adalah persamaan isi cerita meskipun dengan detil yang hampir sama. Kedua, cara penyampaian keduanya teramat berbeda. Ada pengaruh kultural yang sangat kuat yang membedakan Centhini Tambangraras dengan Les Chants de l'Île à Dormir Debout. Pada versi Tambangraras, kevulgaran tersebut diterjemahkan. Dapat diasumsikan bahwa penerjemah tidak melakukan banyak adaptasi dan penambahan-penambahan lain. Sementara itu, versi Inandiak menunjukkan kultur Prancis yang sangat lekat. Penggunaan metafora seperti poisson (ikan) atau untuk alat kelamin laki-laki adalah contohnya. Hal-hal yang vulgar dijelaskan dengan menggunakan metafora-metafora seperti pada kalimat terakhir kutipan Inandiak di atas.

Sementara itu, dalam versi terjemahan Inandiak ke dalam Bahasa Indonesia tidak ditemukan bagian ini. Dapat diintepretasikan bahwa meskipun versi Prancis yang ditulis menggunakan cara-cara lebih halus daripada versi terjemahan ke bahasa Indonesia, sangat tidak mudah untuk menerjemahkan dan menginterpretasikan kembali metafora-metafora itu ke dalam bahasa Indonesia. 
Dalam penerjemahan, karena terlibatnya penerjemah dan interpreter secara subjektif dan emosional, ada keengganan secara psikologis dan kemudian mencoba untuk menghindarinya.

Pada terjemahan Prancis ke Indonesia, ada seleksi ketat terhadap bagianbagian yang diterjemahkan. Ada peringkasan-peringkasan yang dilakukan. Tembang-tembang yang diringkas adalah Tembang 1 sampai 10. Terjemahan dilakukan pada tembang 11 sampai 24 yang diberi judul Pengembaraan. Peringkasan dilakukan lagi pada tembang 25 sampai 59 yang di dalamnya berisi cerita Cebolang. Cerita dilanjutkan dengan penerjemahan terhadap tembang 60 sampai 70. Peringkasan cerita dilakukan lagi pada tembang 71 sampai 114 yang diberi judul Centhini Empat Puluh Malam dan Satunya Hujan. Tembang 115 sampai 122 kembali diterjemahkan dan diringkas kembali pada tembang 123 sampai 129. Tembang 130 sampai 133 merupakan bagian akhir yang diterjemahkan.

Inandiak, yang juga menjadi penerjemah karya ini melakukan pertimbanganpertimbangan atas pilihan-pilihan tersebut. Meskipun dia menerjemahkan karyanya sendiri dari Bahasa Prancis, dalam hal ini ada proses interpretasi yang dilakukan. Kenyataan bahwa inandiak telah lama tinggal di Indonesia menyebabkannya memahami kultur setempat yang merupakan pertimbangan dasar pilihan-pilihan serat yang diterjemahkannya. Ada kesan bahwa Inandiak ingin menjelaskan bahwa Serat Centhini bukan sekedar karya yang berisi tembang-tembang dengan bait-bait yang erotis tetapi memiliki kedalaman makna lebih dari itu. Inilah alasan mengapa tembang 25 sampai 59 yang sarat dengan fenomena tersebut hanya diringkas saja. Bagian tembang 71 sampai dengan 114 serta tembang 123 sampai 129 yang berisi adegan-adegan seksual juga diringkas saja oleh Inandiak dan Lesmana. Yang menjadi aksen dari versi "Centhini Ia yang Memikul Raganya" adalah murni cerita yang berisi kejadian-kejadian yang membangun alur cerita. Pengembaraan dan perjuangan tokoh-tokoh dalam memahami makna hidup berada pada bagian-bagian yang diterjemahkan.

Proses penerjemahan dari Serat Centhini Tambangraras ke Les Chants de Lîle à Dormir Debout ke Ia yang Memikul Raganya menunjukkan intervensi penerjemah yang sangat ketat. Terjadi inovasi-inovasi dalam hal pemilihan bagian yang dalam versi Les Chants de L'Tle à Dormir Debout diperkaya dengan storage Inandiak terhadap karya-karya lain yang dibacanya. Dapat dilihat bahwa unsurunsur karya-karya dan tulisan asing muncul di situ membangun cerita sehingga Centhini memiliki wajah baru tanpa kehilangan jiwanya. Inovasi yang lain adalah proses seleksi terhadap karya-karya yang diputuskan untuk diterjemahkan. Ada storage lain, yakni pemahaman penerjemah terhadap kultur Jawa masa kini dengan situasi social dan politik yang berbeda dengan ketika Serat Centhini itu sendiri dilahirkan. Represi-represi terhadap hal-hal yang sifatnya seksual dalam kultur baru ini kemungkinan juga menjadi salah satu alasan peringkasanperingkasan yang dilakukan. 


\section{SIMPULAN}

Dari pembahasan di atas, dapat disimpulkan bahwa persoalan penerjemahan dan penginterpretasian karya-karya sastra melibatkan secara total ide penerjemah. Dalam proses tersebut memang ada pendekatan objektif yang melihat teks sebagai sebuah entitas yang memaknai dirinya sendiri tetapi dalam realita terjemahan-terjemahan karya-karya centhini di atas, ada proses subjektivikasi yang sangat penting yang menyebabkan penerjemah memberikan masukanmasukan secara kultural terhadap karya-karya terjemahannya.

Terjadi proses yang beragam dari pengembaraan Serat Centhini ke Prancis dan pulang kampung ke Indonesia tersebut. Penerjemah memiliki peran yang besar dari segi pengalihan bahasa. Namun, peran yang lebih besar adalah dari alih budaya yang dilakukan oleh penerjemah yang memiliki subjektivitas dalam proses penerjemahan.

Proses interpretasi dimulai dalam bentuk-bentuk seleksi terhadap teks-teks yang diterjemahkan. Distorsi-distorsi muncul dengan adanya pemunculan hal-hal yang tidak ada dalam karya yang terdahulu atau sebaliknya dengan adanya penghilangan-penghilangan yang disengaja maupun tidak disengaja dari karyakarya yang diterjemahkan. Inovasi-inovasi juga dilakukan dengan memberikan nuansa-nuansa disesuaikan dengan kode budaya tempat karya yang diterjemahkan itu akan dibaca. Dalam konteks bahasa Prancis, aksen-aksen kultur Prancis, misalnya dengan referensi ke karya-karya Prancis dan referensi-referensi prancis lainnya juga dilakukan. Sementara itu dari karya Prancis yang diterjemahkan ke dalam bahasa Indonesia, penyesuaian dengan kultur social dan politik Indonesia aktual dipertimbangkan dalam seleksi penerjemahan. Distorsi dan inovasi tersebut menjelaskan peran penerjemah yang sangat besar sebagai yang turut menginterpretasi sebuah teks.

Ada satu pesan menarik dari pengembaraan Serat Centhini, yakni bahwa penerjemahan adalah penyampaian pesan. Penyampaian pesan sebetulnya bersifat situasional karena dibaca oleh masyarakat pada situasi dan kondisi sosial, budaya dan politik yang berbeda-beda. Memang penerjemahan pada dasarnya menginginkan bahwa teks itu yang menjadi sentral sehingga dapat bercerita kepada siapa saja dan pesannya diterima secara sama oleh orang-orang dengan bahasa yang berbeda. Namun, ketika situasi orang-orang dengan bahasa dan budaya itu berbeda, maka interpretasi penerjemah dengan kecerdasan sosial dan kulturalnya menjadi lebih menarik daripada hanya melihat teks yang berbicara.

\section{DAFTAR PUSTAKA}

Boellstorff, Tom. 2005. The Gay Archipelago : Sexuality and Nation in Indonesia. United Kingdom : Princeton University Press

Durieux, Christine. 2000. "Kreativitas dalam Teknik Penerjemahan" dalam Esther Yonita (penerjemah) Pengantar Penerjemahan, Jakarta: Pusat Penelitian Kemasyarakatan dan Budaya Universitas Indonesia, pp. 1-12. 
Pengembaraan Serat Centhini dalam Centhini Les Chants De L'île À Dormir Debout dan Ia

Yang Memikul Raganya: Interpretasi, Inovasi dan Distorsi dalam Penerjemahan (Wening Udasmoro)

Eco, Umberto. 1979. A Theory of Semiotics, Bloomington : Indiana University Press

Faridl, Miftah. 2007. Ibadah Kaya Makna. Jakarta: Gema Insani

Hadidjaja, Tardjan \& Kamajaya. 1979. Serat Centhini; Ensiklopedi Kebudayaan Jawa. Yogyakarta : U.P. Indonesia

Inandiak, Elisabeth. 2005. Les Chants de l'T̂le à Dormir : Le Livre de Centhini. Gordes : les Editions Relié.

Jacobsen, Arnt Lykke \& Inger M Mees. 2009. Methodology, Technology and Innovation in Translation Process Research. Frederikberg 》 Samfundslitteratur.

Lavault, Elizabeth. 2000. "Penerjemahan Pedagogis atau Pedagogi Penerjemahan?" dalam Esther Yonita (penerjemah) Pengantar Penerjemahan, Jakarta: Pusat Penelitian kemasyarakatan dan Budaya Universitas Indonesia, pp. 13-26.

Le Féal, Karla Déjean. 2000. "Pedagogi Penerjemanan: Sebuah Pemikiran" dalam Esther Yonita (penerjemah) Pengantar Penerjemahan, Jakarta: Pusat Penelitian Kemasyarakatan dan Budaya Universitas Indonesia, pp. 27-102.

Lesmana, Laddy \& Elisabeth Inandiak. 2007. Ia yang Memikul Raganya. Yogyakarta: Galang press.

Marsono. 2002. Centhini Tambagraras-Amongraga Jilid V. Yogyakarta: Gadjah Mada University Press.

Nurnaningsih. 2010. Kajian Stilistika Teks Seksual Dalam Serat Centhini Karya Pakubuwana V. Tesis. Program Pascasarjana Universitas Sebelas Maret Surakarta.

Palmer, Richard E. 1969. Hermeneutics: Interpretation Theory in Schleimacher, Dilthey, Heiddeger and Gadamer, Evanston: Northwestern University Press.

Sumahatmaka, R.M.A. 1981. Ringkasan Centini (Suluk Tambanglaras), PN Balai Pustaka, Cetakan pertama.

Toer, Pramoedya Ananta. 1980. Bumi Manusia. Jakarta: Hasta Mitra 